\title{
Evaluation Of Transforming Growth Factor $\alpha$ (Tgf- $\alpha$ ) And Epidermal Growth Factor Receptor (Egfr) Expression In Oral Squamous Cell Carcinoma
}

\author{
*Effat A. Abbas, **Wafaa E. Abdel-Aal And ***Aml A. Samy \\ *Basic Medical Sciences Department, **Medical Division, National \\ $* * *$ Research Center
}

\begin{abstract}
Objective: The present study aimed to investigate the pattern of expression of transforming growth factor $\alpha$ (TGF- $\alpha$ ) and epidermal growth factor receptor (EGFR) in oral squamous cell carcinoma (OSCC) and to correlate their expression with tumor grading.

Methods: The work was performed on 30 cases of OSCC using immunohistochemistry. Results: For both markers, positive staining reaction was characterized by cytoplasmic or cytoplasmic and membranous staining. EGFR was expressed in $66.7 \%$, while TGF$\alpha$ was expressed in $50 \%$ of cases of oral squamous cell carcinoma. The reaction was particularly strong at the margin of invading cords and nests of tumour cells and poorly differentiated malignant cells. The expression of both markers was significantly correlated with histological grading; while the staining intensity showed no correlation with tumor grading.

Conclusion: This study showed that OSCC express both EGFR and TGF- $\alpha$ and their expression indicated that these markers may have a potential diagnostic value in histologic examination. In addition their increased expression in high tumour grades suggest that they may be used as indicators of tumor aggressiveness.
\end{abstract}

Key words: Oral Squamous cell carcinoma, epidermal growth factor receptor, transforming growth factor- $\alpha$ and immunohistochemistry.

\section{Introduction}

Oral squamous cell carcinoma is a common neoplasm frequently pursuing an unfavorable evolution. Despite progress in diagnosis, no major breakthrough has occurred in recent years either in disease treatment or its prognostication. Specifically, the tradit ional morphological evaluation of these tumours, namely in biopsy material, has limited utility as an aid for therapeutical decision and as an independent variable with definite prognostic impact (Pindborg et al,. 1997).
The expression of several growth factors and their receptors are thought to play a crucial role in the progression of many tumours (Castellini et al., 1994, Shirari et al, 1995 and Wang et al, 1995). EGFR and TGF- $\alpha$ are involved in normal growth and differentiation of oral keratinocytes (Donnelly et al, 1993).

EGFR is a transmembrane
glycoprotein with three distinct
domains: an external ligand binding
domain, a short intramembranous


segment and an intra cellular cytoplasmic domain with tyrosin kinase activity (Chen et al., 1989; Sriplakich et al., 1999). It has a critical role in cell growth and appears to be an important feature of malignant transfor ation of transitional epithel ium (Turkeri et al., 1998).

TGF- $\alpha$ is an EGFR ligand which is distinguished from EGF by its acid labile structure and potent transforming function (Ouyang et al., 1999). It has a wide range of biological activities including regulation of cell growth and differ rentiation of self renewing epithelia through its interaction with EGFR (Gangarosa et al., 1996). It has been shown that TGF- $\alpha$ plays an important role in oral carcinogenesis (Todd, 1991 \& Worng, 1993).

EGFR can bind and be activated by EGF, TGF- $\alpha$ and amphiregulin. Stimulation by any of these may promote DNA replication followed by cell division. Several tumour cell lines coexpress TGF- $\alpha$ and EGFR, suggesting that TGF- $\alpha$ may interact with EGFR on the same cell or its neighbors to support proliferation (Grandis et al, 1996 \& Seiplakich et al, 1999)

Increased expression of EGFR and TGF- $\alpha$ in squamous cell carcinoma of the head and neck has been observed (Grandis and Tweardy, 1993), suggesting that their high expressions may constitute useful early markers in head and neck carcinogenesis.

In the present study, immunoh istochemistry has been used to study the pattern of expression of EGFR and TGF- $\alpha$ in oral squamous cell carcinoma and to correlate their expression with tumor grading.

\section{Material And Methods}

Thirty paraffin blocks of oral squamous carcinomas were included in this study. They were prepared from cases obtained from diverse sources. The cases were graded histologically according to the criteria of the World Health Organization (WHO), (Pindborg et al, 1997). In the present study the cases were divided into low grade (GI) and high grade (GII and GIII) tumors (8 cases of low grade and 22 were of high grade). Five specimens composed of normal mucosa adjacent to tumors were included and served as a control. From each case, four microns thick paraffin sections were prepared and one slide was stained with hematoxylin and eosin for routine histopathological exami nation.

Immunohistochemistry: For imm unohistochemical staining of EGFR and TGF- $\alpha$, standard streptavidin-biotin complex technique was used. Two slides from each case were deparaffinized in xylene, rehydrated in graded alcohol and incubated in 3\% hydrogen peroxide for 30 minutes to block the internal peroxidase activity. Antigen retrieval was done by microwave pretreatment for 10 minutes in 0.01 citrate buffer. Non specific binding sites were blocked by 20 minutes incubation with normal blocking serum. For each case, one slide was incubated with mouse monoclonal EGFR antibody (Novocastra laborat ories Ltd.) diluted at 1:10 in PBS and the other slide was incubated with mouse monoclonal TGF- $\alpha$ antibody (Oncogen Research Products) with a concentration of $10 \mu / \mathrm{ml}$ in PBS at room temperature over night. The staining was completed with avidin-biotinperoxidase complex method using Novostain Universal Quick Kit (Novocastra Laboratories Ltd). Colour development was achieved using 2, 3 diaminobenzidin (DAB). The sections were then counter stained using hematoxylin, cleared and mounted. 
Negative control was obtained by omitting the primary antibody.

Assessment of immunostaining: For both markers, EGFR and TGF- $\alpha$, immunoreactivity in the cytoplasm and cell membrane were looked for and absence of staining at both sites was interpreted as a negative result. For both markers, staining intensity was scored semiquantitavely as mild $(+)$, moderate $(++)$, or strong $(+++)$ (Tungekar and Linehan, 1998).

Statistical analysis: Differences in the distribution of variables between groups were tested using the Chi-Square test. If - $P$ value was less than 0.05 , the difference was considered significant.

\section{Results}

A total of 30 cases of oral squamous cell carcinoma (OSCC) and five normal oral mucosa have been studied in this work. The studied cases were analyzed immunohistochemically using anti-EGFR and anti-TGF- $\alpha$ monoclonal antibodies.

Normal oral mucosa stained positive in some of the basal and suprabasal cells for both TGF- $\alpha$ and EGFR. Staining for both antigens within the epithelium was primarily localized in the cytoplasm. Only one specimen of control mucosa exhibited positive for staining EGFR at cell membrane.

Immunostaining for EGFR was detected in 20 out of 30 OSCC cases (66.7\%) table (1). Positive staining reaction was characterized by cytoplasmic or cytoplasmic and membranous staining. While TGF- $\alpha$ was detected in 15 out of 30 OSCC cases $(50 \%)$ (table 3$)$. Positive staining reaction was characterized by cyto plasmic staining only. The reaction was particularly strong at the margin of invading cords and nets of tumour cells and poorly differentiated malignant cells.

For tumour expressing epidermal growth factor receptor $25 \%$ was of low grade and $75 \%$ was of high grade (table 1). Six cases showed mild staining intensity, 7 were moderate intensity, where strong staining was detected in the remaining 7 cases.

Mild staining was detected in both low grade and high grade tumors, while most of the strongly stained tumors were of high grade (table 2).

These results showed that EGFR immunoreactivity was significantly correlated with histologic grading $(\mathrm{P}<$ 0.05). Staining intensity showed no significant correlation with tumor grading in OSCC $(\mathrm{P}>0.05)$.

Of the 15 TGF-a positively stained OSCC cases, low grade tumors represented $13.3 \%$, while the remaining $86.7 \%$ were of high grade (table 3 ). Two cases revealed mild staining intensity, moderate intensity was detected in 8 cases, and the remaining 5 cases were strongly stained.

From these results, it was found that TGF- $\alpha$ expression were signif icantly correlated with tumor grading $(\mathrm{P}$ $<0.05)$, while the staining intensity does not such correlation $(\mathrm{P}>0.05)$.

Figures (1-4) showed the expression of both markers in low and high grades of OSCC.

Table (1): Correlation of EGFR immunoreactivity with tumour grading in oral squamous cell carcinoma.

\begin{tabular}{|l|l|l|l|l|}
\hline & LG & HG & Total & $P$-value \\
\cline { 1 - 4 } - ve & $3(30 \%)$ & $7(70 \%)$ & $10(33.3)$ & \multirow{3}{*}{$P<0.05$} \\
\hline +ve & $5(25 \%)$ & $15(75 \%)$ & $20(66.7 \%)$ & \\
\hline total & $8(26.7 \%)$ & $22(73.3 \%)$ & $30(100 \%)$ & \\
\hline
\end{tabular}


Table (2): EGFR staining intensity in oral squamous cell carcinoma.

\begin{tabular}{|l|l|l|l|l|}
\hline & LG & HG & Total & \multirow{2}{*}{$P$-value } \\
\hline Mild & $2(33.3 \%)$ & $4(66.7 \%)$ & $6(30 \%)$ & \multirow{3}{*}{$P>0.05$} \\
\cline { 1 - 4 } Moderate & $2(28.6 \%)$ & $5(71.4 \%)$ & $7(35 \%)$ & \\
\cline { 1 - 4 } Strong & $1(14.3 \%)$ & $6(85.7 \%)$ & $7(35 \%)$ & \\
\cline { 1 - 4 } Total & $5(25 \%)$ & $15(75 \%)$ & $20(100 \%)$ & \\
\hline
\end{tabular}

Table (3): Correlation of TGF- $\alpha$ immunoreactivity with tumour grading in oral squamous cell carcinoma.

\begin{tabular}{|l|l|l|l|l|}
\hline & LG & HG & Total & $P$-value \\
\cline { 1 - 4 } - ve & $6(40 \%)$ & $9(60 \%)$ & $15(50 \%)$ & \multirow{3}{*}{$P<0.05$} \\
\cline { 1 - 4 } +ve & $2(13.3 \%)$ & $13(86.7 \%)$ & $15(50 \%)$ & \\
\hline total & $8(26.7 \%)$ & $22(26.7 \%)$ & $30(100 \%)$ & \\
\hline
\end{tabular}

Table (4): TGF- $\alpha$ staining intensity in oral squamous cell carcinoma.

\begin{tabular}{|l|l|l|l|l|}
\hline & LG & HG & Total & $P$-value \\
\hline Mild & 0 & $2(100 \%)$ & $2(13.3 \%)$ & \multirow{3}{*}{$P>0.05$} \\
\cline { 1 - 4 } Moderate & $2(25 \%)$ & $6(75 \%)$ & $8(53.4 \%)$ & \\
\cline { 1 - 4 } Strong & 0 & $5(100 \%)$ & $5(33.3 \%)$ & \\
\hline Total & $2(13.3 \%)$ & 13 & $15(100 \%)$ & \\
\hline
\end{tabular}

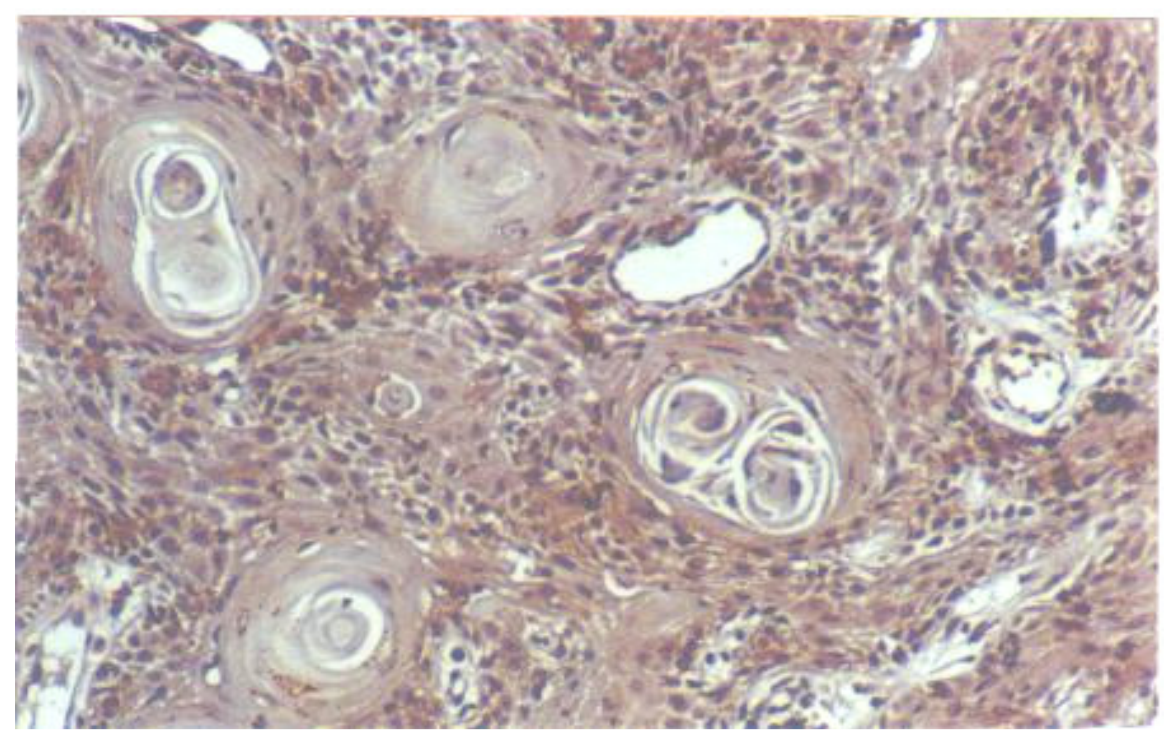

Fig (1): Low grade oral squamous cell carcinoma showing positive reaction for TGF-á (immunoperoxidase X 150). 


\section{Evaluation Of Transforming Growth Factor}

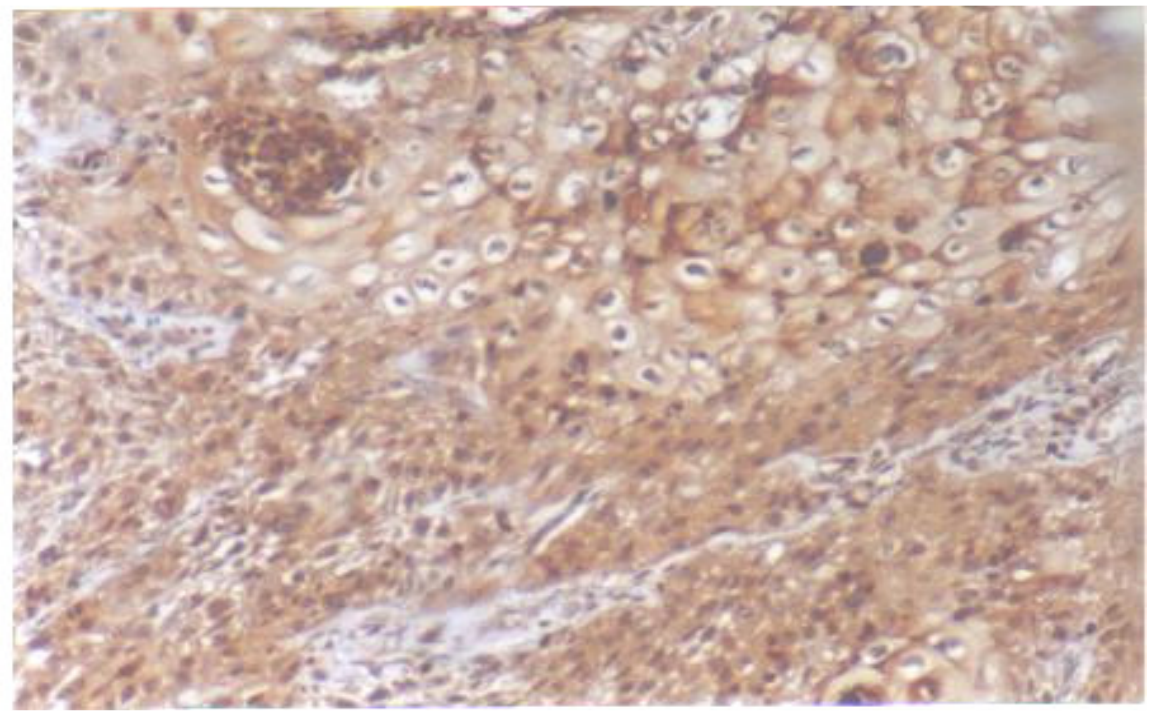

Fig (2): High grade oral squamous cell carcinoma showing positive reaction for TGF-á (immunoperoxidase X 150).

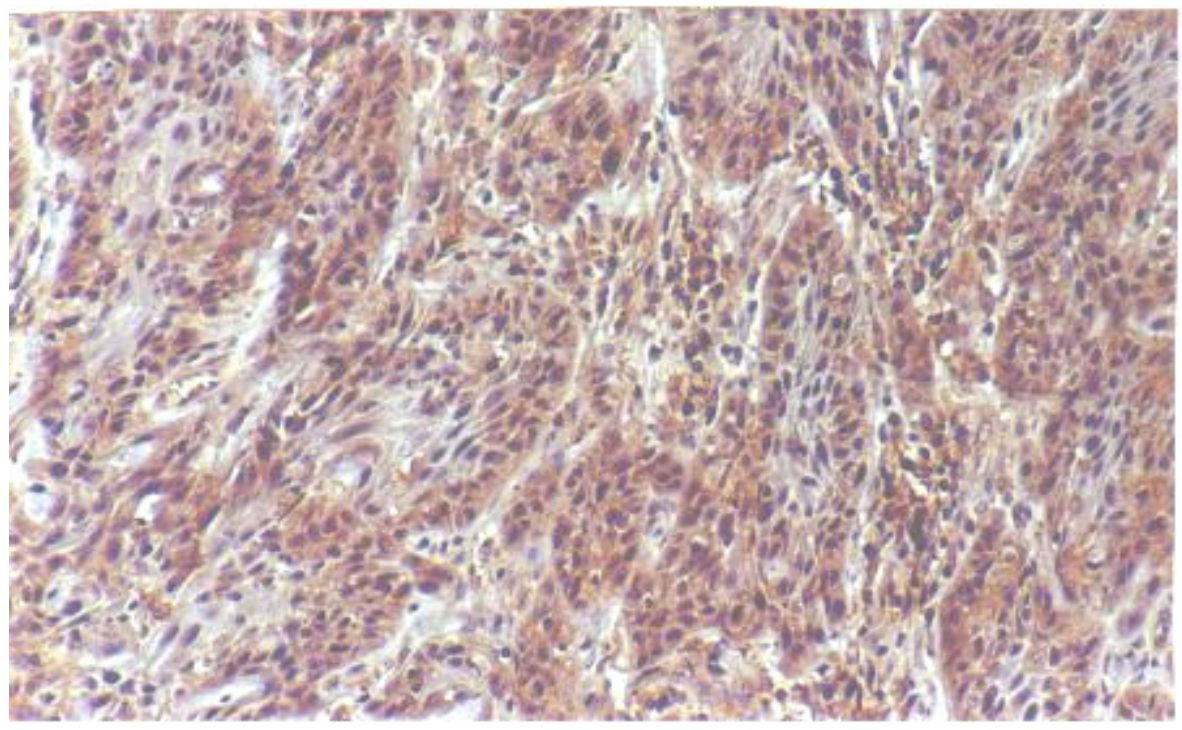

Fig (3): Membranous staining for EGFR in high grade squamous cell carcinoma (immunoperoxidase X 300). 


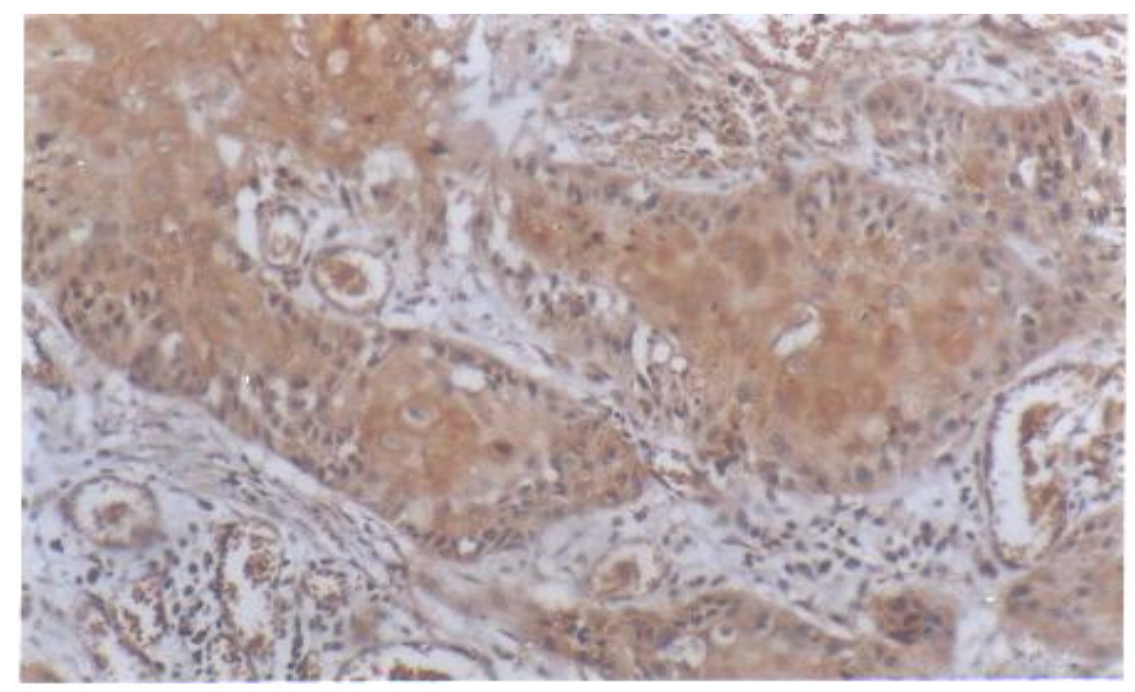

Fig (4): Cytoplasmic staining for EGFR in low grade squamous cell carcinoma (immunoperoxidase X 300).

\section{Discussion}

EGFR is an activated oncogen associated with human tumor biology. Enhanced expression of EGFR is frequently detected in a variety of carcinomas, including breast, lung, bladder and head and neck (Tang et al., 2000). TGF- $\alpha$ is an epidermal growth factor receptor ligand. It can bind and activate EGFR, promoting DNA replication and cell division.

Recent studies indicate that EGFR expression and the presence of EGF and / or TGF- $\alpha$ take part in neoplastic processes (Turkeri et al., 1998). They play an important role through the autocrine growth regulation system in several human cancers (Tamekita et al., 2000).

In the present study we aimed to detect, immunohistochemically, the expression of EGFR and TGF- $\alpha$ in oral squamous cell carcinoma and to correlate their expression with tumor grading.

Our observation of positive expression for TGF- $\alpha$ and EGFR in the cells of the control oral mucosa was

consistent with the report of Kannan et al., (1996) and Srinivasan \& Jewell (2001). Their reports showed that both markers were weakly expressed in the cytoplasm of the basal and suprabasal layers of the normal oral mucosa.

In the present study, EGFR and TGF- $\alpha$ were detected in $66.7 \%$, and $50 \%$ of cases of oral squamous cell carcinoma respectively. Their expression showed linear increase with higher grades $(p<0.05)$, but the staining intensity did not show significant correlation with tumour grading. The immunostaining of malignant cells for EGFR was either cytoplasmic or cytoplasmic and membranous, while for TGF- $\alpha$ it was only cytoplasmic. Similar results were detected by Grandis and Tweardy (1993) and Grandis et al, (1996) who observed increased expression of EGFR and TGF- $\alpha$ in squamous cell carcinoma of the head and neck.

In the present study, the malignant cells showed the highest expression of TGF- $\alpha$ and EGFR localized at the 
peripheral margins of the invading tumour cords and in poorly differentiated malignant cells. These results were in agreement with the reports of TGF- $\alpha$ MRNA occurrence in malignant keratinocyte cell lines in culture (Grandis and Tweadry 1993 and Prime et al, 1993).

There were few reports studying the expression of TGF- $\alpha$ and EGFR in OSCC, however Srinivasan and Jewell (2001) tried to detect both markers in oral premalignant lesions. They showed that the high expression of EGFR and TGF- $\alpha$ correlated with the degree of epithelial dysplasia. These data suggested increased receptors ligand interaction with increasing degrees of dysplasia, and also support the hypothesis that increased expression of EGFR and TGF- $\alpha$ is associated with early events in head and neck cancer (Grandis and Tweadry 1993). Similar trends were observed in the premalignant lesions of vocal cords (Miyaguchi et al, 1991) and stomach (Fillip et al, 1995).

Grandis and Tweadry (1993) and Grandis et al, (1996) have reported that TGF- $\alpha$ induced proliferation and expression of EGFR in cancer cells. Their reports also suggested that increased expression of EGFR may be a better prognostic indicator of oral cancer than conventional clinical parameters. On the other hand; the observation of Srinivasan and Jeweel (2001), showed that increased expression of TGF- $\alpha$ by the basal and the parabasal cells may provide an early marker for the onset of epithelial dysplasia preceding oral cancer.

In conclusion, the immuno histochemical detection of EGFR and TGF- $\alpha$ in oral squamous cell carcinoma indicates that these markers have a potential diagnostic value in histological examination. In addition, their increased expression in high tumour grades suggest that they may be used as indicators of tumour aggressiveness.

\section{References}

1.Castellini R. Vischcr D. W., Wykes S., Sarkar F. H., Crissman J.D., (1994): Interaction of transforming growth factor- $\alpha$ and epidermal growth factor receptor in breast carcinoma: An immunohistoc hemical study. Cancer; 73: 344-349.

2.Chen W. S., Lazar C. S., Lund K. A., et al. (1989): Functional independence of the epidermal growth factor receptor from a domain required for ligand-induced internalization and calcium regulation. Cell; 59: 33-43.

3.Donnelly M. J., Patel V., Yeudall W. A., Game S. M., Scully C., Prime S. S., (1993): Autocrine production of TGF-alpha and TGFbeta during tumor progression of rat oral keratinocytes. Carcinogenesis; 14: 981-985.

4.Fillip M. I., Osborn M., Linchan J., Sanidas E., Brito M. J., Janowski J. (1995): Expression of transforming growth factor-alpha, epidermal growth factor receptor in precursor lesions to gastric carcinoma. Br. J. Cancer;71: 30-36.

5.Gangarosa L. M., Dempsey P. J., Damstrup L., et aL (1996): Transforming growth factor- alpha. Baillieres Clin, Gastroenterol.; 10; 49-63.

6.Grandis J. R., Melhem M. F., Barens E. L., Twardy D. J. (1996): Quantitative immunohistochemical analysis of transforming growth factor-alpha and epidermal growth factor receptor in patients with squamous cell carcinoma of the head and neck. Cancer; 78: 12841292. 
7.Grandis J. R., Tweardy D. J., (1993): Elevated levels of transfo rming growth factor-alpha and epidermal growth factor receptor messenger RNA are early markers of carcinogenesis in head and neck cancer. Cancer Res.; 53:3579-3584.

8.Kannan R, Bijur G N, Mallery S R, Beck M F, Sabourin CLK, Jewell SD, Sculler DE, Storer GD (1996): Transforming growth factor-alpha overexpression in proliferative verrucous leukoplakia and oral squamous cell carcinoma. An immunohistochemical study. Oral surg Oral Med. Oral Path. Oral Radical Grelocl. ; 82: 69-74.

9.Miyaguchi M., Olofsson J, Hcllquist H. B., (1991): Immunohistochemi cal study of epidermal growth factor receptor in severe dysplasia and carcinoma in situ of the vocal cords. Acta Otolaryngol; 111: 149-152.

10. Ouyang X., Gullitbrd T., Iluang G., and Epstein R. ,1. (1999): Transforming growth factor-alpha short circuits downregulalion of the epidermal growth factor receptor. J.Cell Physiol.; 179 (I): 52-7.

11. Pindborg JJ, Reichart PA, Smith CJ. Et al., (1997): International typing of cancer and precancer of the oral mucosa . "World Health Organization International Histological Classification of Tumour": $2^{\text {nd }}$ ed: Beilin Heidberg: Springer-Verlag.

12. Shirai H, Ueno E. Osaki M, Tatebe $\mathrm{S}$, Ito $\mathrm{H}$, Kaibara $\mathbf{N}$ (1995): Expression of growth factors and their receptors in human early colorectal carcinomas. Immunohistochemical study. Anticancer Res.; 15: 2889-2894.

13. Srinivasan, M. and Jewell S. D. (2001): Evaluation of TGF- $\alpha$ and EGFR expression in oral leukoplakia and oral submucous fibrosis by quantitative immunohi stochemistry. Oncology; 1 (61): 284-292.

14. Sriplakich S., Jahnson S., and Karlsson M. G. (1999): Epidermal growth factor receptor expression: predictive value for the outcome after cystectomy for bladder cancer. BJU International: 83: 498-503.

15. Tang C. K., Gong X. Q., Moscatello D. K., Wong A. J., and Lippman M. E. (2000): Epidermal growth factor receptor VIII enhance tumorigenicity in human breast cancer. Cancer Research; 60: 30813087.

16. Todd R., Chou M. Y., Matossian K., Gallagher GT, Donoff R. B., Wong D. J. W., (1991): Cellular sources of transforming growth factor-alpha in human oral cancer. J. Dent. Res. ;70:917-923.

17. Tungekar M. F., and Linchan .1. (1998): Patterns of expressions of transforming growth factor and epidermal growth factor receptor in squamous cell lesions of the urinary bladder. J. Clin. Pathol.; 51: 583587.

18. Turkeri L. N., Erton M. L., Cevik I., and Akdas A. (1998): Impact of the expression of epidermal growth factor, transforming growth factor alpha, and epidermal growth factor receptor on the prognosis of super ficial bladder cancer, Urol; 51: 645649.

19. Wang X. M., Tang Z. Y., Xue Q, Hong X. Y., Bao WH, Zou H. Q., (1995): Transforming growth factor-alpha induces proliferation and expression of epidermal growth factor receptor in hepatocellular carcinoma. J. Exp. Clin. Cancer Res.; 14:79-84.

20. Worng DTW. (1993): TGF- $\alpha$ and oral carcinogenesis. Eur. J. Cancer; 29 (B): 3-7. 


\section{دراسة وجود مستقبلات عامل النمو الآدمي وعامل النمو التحولي ألفا في سرطان الفم}

\section{عفت احد عباس .... وفاء عبد العال..... أمل عبد الرحم \\ قسم العلوم الطبية الأساس ة .. شعبه البحوث الطبية .. المركز القومي للبحوث . .}

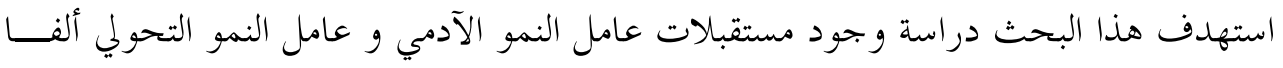

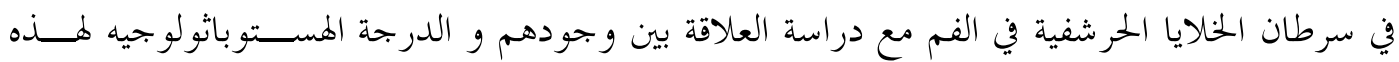

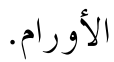

تم إجراء الدراسة على 30 حالة من سرطان الخلايا الحرشفيه و ذلك باستخدام هســتو كيمياء

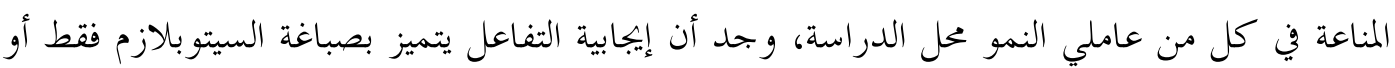

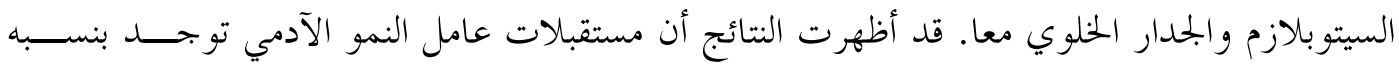

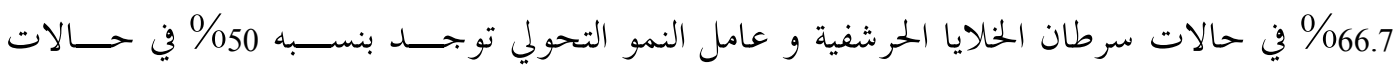

$$
\text { سرطان الخلايا الحرشفية. }
$$

ووجد أن التفاعل قوى عند الحواف وفي وسط الخلايا السرطانية والخلايا فقيرة التميز. لقد وجدت علاقة ذات دلالة إحصائية بين وجود مستقبلات عاملي النمو الآدمي و التحــــلي

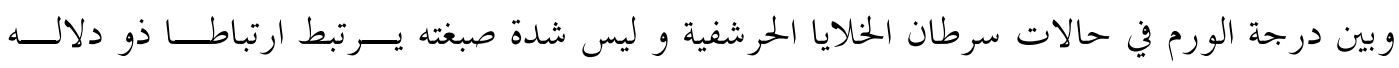
إحصائية بدرجة الورم.

من هذا البحث نستنتج أن أورام الفم تنتج مستقبلات عامل النمو الآدمي وعامل النمو التحولي

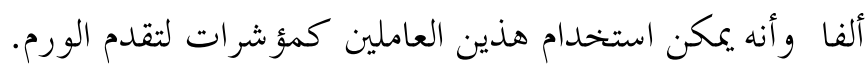

